\title{
Model Pemrosesan Informasi pada Intensitas Perilaku Hate Speech Pengguna Media Sosial
}

\author{
Nida'an Fajriyah $^{1}$, Hudaniah ${ }^{2}$, Susanti Prasetyaningrum ${ }^{3}$ \\ Fakultas Psikologi, Universitas Muhammadiyah Malang \\ e-mail: ${ }^{1}$ Fajriyah27@gmail.com, ${ }^{2}$ hudaniah_hudaniah@yahoo.com, \\ ${ }^{3}$ santiwahyudi20@gmail.com
}

\begin{abstract}
The intensity of hate speech behavior is the level of one's activities in showing negative evaluations as well as justifying and spreading hatred upon others. The rising number of cases of hate speech, bullying, racism, and so on in social media, made researchers interested in conducting research on how students' strategies in processing information obtained on social media. This study aims to determine the intensity of hate speech behavior by social media users on the selection of information processing strategies or messages on social media. This research incorporates a descriptive quantitative research model. The subjects of this study amounted to 158 people age 19-25 years who were selected using the accidental sampling technique. The research instruments in the present study are the information processing scale and hate speech behavior scale. The results showed that social media users in this study tended to use heuristic processing types $(61 \%)$, systematic (35\%), and systematic-heuristic (3\%) which demonstrate that most social media users tended to think simply about the content of any information in social media.
\end{abstract}

KEYWORD Social media, information processing, hate speech.

CITATION Fajriyah, N., Hudaniah., \& Prasetyaningrum, S. (2019). Model pemrosesan informasi pada intensitas perilaku hate speech pengguna media sosial. Cognicia, 7, (2), 175-191.

Masyarakat modern pada masa ini tidak terlepas dari pesatnya kemajuan teknologi komunikasi dan media massa, yang disebut dengan masyarakat informasi (information society). Asosiasi Penyelenggara Jasa Internet Indonesia (APJII) mengungkap data penggunaan dalam jenis konten internet yang diakses tertinggi di Indonesia adalah media sosial sebanyak $97,4 \%$ atau 129,2 juta jiwa. Sedangkan di tahun 2017 mencapai jumlah 143,26 juta jiwa pengguna, hal ini berarti terjadi peningkatan pada penggunaan media sosial sebanyak 10,56 juta jiwa dari total keseluruhan penduduk Indonesia dari 2016. APJII (2016) juga menunjukkan bahwa berdasarkan usia pengguna internet di Indonesia dengan kisaran usia 19-34 tahun sebanyak 74,23\%. Berdasarkan data tersebut diketahui bahwa pengguna internet kisaran usia 19-34 tahun sangat tinggi persentasenya. Pengguna sosial media sendiri bukan hanya para remaja saja namun mulai dari anak-anak sampai dengan orang dewasa atau tua pun juga mahir dalam menggunakan sosial media dan begitu juga dengan setiap golongan baik pekerja kantoran, pekerja lepas, pedagang, pelajar maupun mahasiswa. Mahasiswa sendiri merupakan masa dimana seseorang sudah memasuki pada masa 
dewasa awal yang ditandai dengan usia mulai dari 18 tahun sampai 25 tahun. Masa ini juga disebut dengan masa peralihan atau transisi dari masa remaja, baik secara fisik (physically), intelektual (cognitive), maupun peran sosial (social role) (Santrok, 2012).

Sebuah penelitian yang dilakukan oleh We Are Social dan Hootsuite, mengatakan bahwa masyarakat Indonesia sangat gemar untuk mengunjungi media sosial, sekitar 130 juta masyarakat Indonesia yang aktif dalam penggunaan media sosial seperti instagram, twitter, facebook, dan lain sebagainya. APJII (2016) mengungkapkan penggunaan dalam jenis konten internet yang diakses tertinggi di Indonesia adalah media sosial sebanyak $97,4 \%$ atau 129,2 juta jiwa. Jumlah waktu yang dapat dihabiskan oleh masyarakat Indonesia dalam bermedia sosial, rata-rata setiap harinya seseorang mampu mengakses sekitar 8 jam 51 menit. Sedangkan lama waktu dalam penggunaan media sosial dari berbagai perangkat mencapai 3 jam 23 menit dalam setiap harinya (okezone.com, 2018). Adapun beberapa jenis media sosial yang dapat digunakan untuk berbagi informasi seperti Instagram, YouTube, Facebook, Google+ dan lain-lain. Asosiasi Penyelenggara Jasa Internet Indonesia (APJII) menunjukkan bahwa adanya tiga media sosial yang paling banyak dikunjungi di Indonesia, yaitu pertama Facebook sebanyak 71,6 juta pengguna (54\%), kemudian yang kedua Instagram sebanyak 19,9 juta pengguna (15\%) dan yang ketiga YouTube dengan pengguna sebanyak 14,5 juta (11\%) (Hidayat, 2016). Penelitian yang dilakukan oleh Alloway (2013) menunjukkan bahwa intensitas penggunaan Facebook pada remaja selama lebih dari satu tahun mendapatkan skor lebih tinggi pada tes kemampuan verbal, memori kerja, dan ejaan dibandingkan dengan mereka yang menggunakan dalam waktu yang lebih singkat.

Topik yang sering serta diminati untuk dibaca oleh kalangan anak muda yang dilansir pada Penulisid (2015) yakni tentang hiburan (film, musik, konser), gosip, game, hal-hal galau dan tentang percintaan, teknologi yang semakin canggih, serta olahraga. Sedangkan menurut Suara.com (2014) mengatakan bahwa terdapat beberapa hal yang paling diinginkan oleh remaja dikehidupannya yakni binatang peliharaan, figur atau tokoh idola, mencoba-coba, ketertarikan dengan lawan jenis, senang bereksplorasi, menjalin pertemanan, ingin tahu, bergaya, suka bergaya di depan kamera. Anak-anak dan remaja memiliki tiga motivasi utama untuk mengakses internet: untuk mencari informasi, untuk terhubung dengan teman (lama dan baru) dan untuk hiburan. Pencarian informasi yang dilakukan sering didorong oleh tugas-tugas sekolah, sedangkan penggunaan media sosial dan konten hiburan didorong oleh kebutuhan pribadi (Kominfo, 2014).

Seiring bertambahnya jumlah pengguna jejaring sosial pada kalangan mahasiswa di masyarakat maka tidak menutup kemungkinan semakin banyak pula masalah yang terjadi di masyarakat. Kita sebagai masyarakat telah hidup pada media saturated era yaitu dimana masyarakat yang hidup di masa sekarang, dan seolah dikelilingi oleh berbagai macam media informasi mulai dari media cetak, media elektronik dan media online secara rapat (Krismanto, Yulia, \& Hasnah, 2017). Istilah media sosial terdiri dari "media" dan "sosial". Media sendiri diartikan sebagai alat komunikasi. Sedangkan "sosial" diartikan sebagai kenyataan pada sosial, yang artinya bahwa setiap perilaku individu memberikan kontribusi kepada lingkungan masyarakat (McQuail, 2003). Media massa terdiri dari berbagai macam jenisnya mulai dari televisi, radio, surat 
kabar, majalah, buku, rekaman, film, hingga internet. Sehingga media saturated era, menuntut para penggunanya agar lebih cerdas dan kritis terhadap konten-konten dalam media sosialnya (Lubis \& Rumyeni, 2013). Namun, seringkali media sosial memberikan dampak perilaku yang positif maupun negatif dalam penggunaannya. Banyak kasus dari dampak negatif penggunaan media sosial yang membuat resah masyarakat atau penggunanya mulai dari bullying, sara, sampai dengan hate speech. Council of Europe hatespeech (2012, dalam Judhita, 2017 ) memahami hate speech sebagai semua bentuk ekspresi yang menyebar, menghasut, mempromosikan atau membenarkan kebencian rasial, xenophobia, anti-semitisme atau lainnya dalam bentuk kebencian berdasarkan intoleransi. Nurhadiyanto (2019) menerangkan bahwa definisi mengenai hate speech di Indonesia sendiri belum memiliki pengertian spesifik secara hukum. Namun secara umum, terdapat 2 hal yang masih berada di wilayah abu-abu yakni hate speech dan pencemaran nama baik. Keduanya dapat dilakukan, baik di dunia nyata dan dunia digital (internet). Baik hate speech dan pencemaran nama baik memiliki kelenturan penafsiran yang berpotensi digunakan untuk mengutamakan kepentingan tertentu. Ilmu psikologi mendefinisikan hate speech sebagai salah satu bentuk perilaku agresi pada seorang individu yang atau dikategorikan dalam perilaku agresi, lebih tepatnya merupakan perilaku agresi verbal aktif tidak langsung. Menurut Buss (1987, dalam Hudaniah \& Dayakisni, 2012), perilaku agresi verbal aktif tidak langsung merupakan suatu tindakan agresi verbal yang dilakukan oleh seorang individu atau kelompok tertentu dengan cara berhadapan secara tidak langsung atau melalui media komunikasi dan informasi dengan individu atau kelompok lain yang menjadi sasaran dalam hate speechnya, seperti menyebar berita tidak benar atau jatuhnya hoax atau fitnah dan mengadu domba antara satu dengan lainnya.

Beberapa contoh kasus ujaran kebencian yang terjadi di media sosial ialah kasus yang menyeret nama Ahmad Dhani. Tulisan pada artikel Tirto.id (2018) dalam kasus tersebut, Ahmad Dhani ditetapkan sebagai tersangka atas pencemaran nama baik dan ujaran kebencian, karena Ahmad Dhani mengatakan kata idiot di vlognya saat dihadang pendemo yang menolak deklarasi \#2019GantiPresiden di Hotel Majapahit Surabaya 26 Agustus 2018 lalu. Kemudian pada Suara.com (2018) mengabarkan bahwa artis Ussy Sulistiawaty perang dengan netizen lantaran anak dan dirinya mendapatkan nyinyiran oleh netizen pada foto yang diunggahnya saat menghadiri acara dari salah satu anaknya, yang kemudian dalam sekejap menimbulkan komentar oleh netizen mengenai gaya busana Ussy dan anak-anaknya dalam foto tersebut. Selain itu ia juga dianggap tak pantas menjadi ibu dari anak ke 3 nya yang bernama Elea lantaran Elea dianggap terlalu cantik dari semua anaknya.

Berdasarkan kasus diatas diketahui bahwa pemanfaatan media sosial yang cenderung meningkat dari tahun ke tahun menimbulkan fenomena seperti setiap orang bebas untuk mengutarakan apa saja sesuai keinginannya melalui akun media sosial yang dimiliki, atau dengan mudahnya mereka dapat membagikan kontenkonten yang ada di akun orang lain dan kemudian dapat dikomentari bebas, baik positif, negatif, maupun netral oleh pengguna lainnya. Istilah bagi perilaku mengenai ujaran kebencian disebut dengan kata lain hate speech. Ahnaf dan Suhadi (2014) dalam penelitiannya mengungkapkan bahwa ujaran kebencian bukan hanya berbahaya bagi koeksistensi antar-kelompok identitas, melainkan juga berbahaya bagi demokrasi. 
Selain itu, ujaran kebencian juga mengandung muatan pesan yang menganggap bahwa kelompok tertentu merupakan warga kelas rendah (subhuman). Sehingga hal itu tidak hanya berbahaya tetapi juga tidak berhak mendapatkan perlakuan setara oleh negara. Pelanggaran hate speech menurut Post (2009, dalam Anhaf \& Suhadi, 2014) akan mengalami problem yang konseptual dalam membedakan antara "hate" dengan "normal dislike" atau "disagreement". Saat ini, hukum hate speech atau ujaran kebencian tidak hanya ditujukan pada publik figur, namun juga masyarakat awam.

Adapun dampak dari perilaku hate speech, menurut hasil riset yang telah dilakukan oleh Yohan (2016) hate speech ialah bermasalahnya komunikasi verbal yang terjadi pada sejumlah mahasiswa yaitu seperti berkurangnya daya konsentrasi, frekuensi dan kesantunan dalam berkomunikasi sesuai akademik karena adanya keterikatan dengan komunikasi pada dunia maya, berkurangnya rasa percaya diri untuk berkomunikasi di kampus, khususnya dengan para dosen, karena adanya sebuah pelarian berupa "curhat" di sosial media (dalam Mawarti, 2018). Dampak lainnya bagi korban perilaku hate speech dilansir dari Internetsehat.id (2014), menurut hasil survey yang telah dilakukan oleh Ditch the Label, sebuah kegiatan amal anti bullying nasional di Inggris, korban mengatakan bahwa efek terburuk dari hate speech adalah jatuhnya harga diri mereka dalam kehidupan sosial, serta merusak masa depan dengan cara menghancurkan optimisme mereka. Hal tersebut sudah harusnya menjadi perhatian yang sangat penting bagi setiap individu. Hate speech atau cyber bullying dalam jenis apapun memilik efek yang sangat buruk pada setiap orang atau individu yang mengalaminya bahkan berujung pada kematian penerima perlakuan tersebut atau pada korban.

Media sosial, bukan hanya memiliki dampak negatif melainkan juga memiliki dampak positif. Berdasarkan dari beberapa hasil penelitian mengungkapkan bahwa adanya dampak positif dari media sosial yang mampu menunjang kebutuhan akademis pada remaja. Hasil penelitian yang dilakukan oleh Visanthi (2016) mengungkapkan bahwa media sosial memiliki potensi untuk menciptakan suatu konteks dan peluang yang baru untuk meningkatkan motivasi pada siswa. Hal tersebut didukung oleh Hasil penelitian Singh (2016) juga mengungkapkan bahwa motivasi pada siswa dapat terjadi karena adanya dukungan yang cukup besar antara keyakinan yang positif dan sikap positif remaja terhadap media sosial untuk pertukaran aktivitas akademis dan kinerja akademis mereka. Tak hanya menunjang pada sisi kognitif, pada sisi afeksi media sosial juga banyak dimanfaatkan untuk memenuhi kebutuhan pribadi penggunanya seperti berbelanja. Seperti halnya Agustina (2016) dalam penelitiannya mengungkapkan bahwa remaja menggunakan media sosial Instagram dan mengikuti akun jual beli pada Instagram-nya guna mempermudah dan mempersingkat waktu dalam berbelanja.

Masyarakat Telematika Indonesia (Mastel) dalam hasil surveinya menunjukkan bahwa adanya ketidakjelasan sumber informasi dalam berita yang beredar $83,2 \%$ responden mengaku langsung memeriksa kebenaran dari berita tersebut, 15,9\% responden mengaku langsung mengahapus atau mendiamkan informasi tersebut, dan 1\% responden mengaku langsung meneruskan berita tersebut (Okezone.com, 2017). Sebagai pengguna media sosial,sudah seharusnya mampu untuk menyaring informasi 
dari konten-konten yang ada di media sosial tersebut. Sehingga tidak terjadi perilaku negatif yang merugikan beberapa pihak lain dalam bersosial media.

Penelitian yang dilakukan oleh Moriansyah (2016), bahwa hasil penelitian menunjukkan motivasi pengguna untuk menggunakan media sosial dan sikap terhadap pesan kampanye terbukti berpengaruh secara signifkan positif pada sikap pengguna terhadap kampanye sosial di media sosial. Serta terdapat perbedaan motivasi yang memengaruhi sikap pengguna media sosial terhadap kampanye pada dua kategori kelompok. Penelitian lainnya, yang dilakukan oleh Supratman (2018) mengatakan bahwa hasil evaluasi pada responden pengguna sosial merupakan suatu proses sosial digital native agar dapat membantu beradaptasi menjadi warga net yang bertanggung jawab. Implikasinya diperlukannya kemampuan dalam hal memahami substansi informasi yang diperoleh melalui pengalaman-pengalaman nyata yang telah dialami, baik itu pengalaman terbaik dan terburuk. Cerminan dari hasil pengalamanpengalaman yang dialami mereka akan mengubah kemampuan untuk lebih cerdas dalam mengambil refleksi dari pengalaman tersebut secara mendalam. Sehingga mereka akan mampu untuk menerjemahkan setiap pengalaman terburuk dalam menggunakan media sosial secara tanggung jawab dan proporsional. Informasi yang didapat dari media sosial juga dapat memberikan pengaruh terhadap sisi kognitif, afektif dan behavioral pada penggunanya. Efek kognitif terjadi, apabila terjadinya perubahan pada pengetahuan dan pemahaman pada apa yang ia dapat. Efek afektif akan muncul ketika adanya perubahan pada apa yang dirasakan, yang biasanya berhubungan dengan sikap atau emosi pada seseorang tersebut. Sedangkan pada efek behavioral lebih merujuk pada perilaku yang dapat diamati dari seseorang tersebut, seperti berbagai pola tindakan, kegiatan, atau kebiasaan berperilaku seseorang (Rakhmat, 2013).

Menurut teori konsistensi (Hudaniah \& Dayakisni, 2012) manusia merupakan pelaku pemrosesan informasi yang aktif yang mencoba untuk memahami seluruhnya yang datang berdasarkan apa yang mereka rasakan, apa yang mereka pikirkan dan bersikap secara aktif untuk menyusun dan menafsirkan dunia tersebut untuk mencocokkan terhadap inkonsisten yang bisa terjadi antara sikap-sikap pada dirinya. Baron dan Byrne (2004) mengatakan bahwa adanya 2 strategi dalam pemrosesan informasi yang dimiliki oleh individu, yaitu pemrosesan sistematis dan pemrosesan heuristik. Pemrosesan sistematik merupakan pemrosesan informasi yang dilakukan oleh indovidu dengan cara memahami maupun analisis yang mendalam terhadap isi pesan tersebut. Sedangkan pemrosesan heuristik merupakan pemrosesan informasi yang tidak membutuhkan analisis yang mendalam melainkan pemrosesan secara sederhana pada pesan tersebut, biasanya sikap pada seseorang terhadap pesan akan mudah untuk dirubah apabila orang tersebut menggunakan strategi pemrosesan heuristik.

Dalam ilmu psikologi mengenai Elaboration Likelihood Model Petty \& Cacioppo (dalam Hudaniah \& Dayakisni, 2012), adanya pemrosesan informasi yang dibagi menjadi dua, yakni central route, yaitu pemrosesan informasi dilakukan dengan cermat dan sangat hati-hati, dan peripheral route, dimana proses pemrosesan informasi dilakukan dengan cara sederhana dan tidak memerlukan analisis secara cermat terhadap informasi yang diperoleh. Pada penelitian di bidang psikologi, Emerson dan 
Conroy (2006, dalam Astarani, 2010) menggunakan model ELM Petty dan Cacioppo (1986) untuk menjelasakan perubahan perilaku akibat terjadinya suatu peristiwa tertentu. Pada penelitiannya mereka menyelidiki mengenai perubahan perilaku akibat terjadinya kasus Enron dan ImClone, atas persepsi mahasiswa dari berbagai bidang studi terhadap accounting tricks dan insider trading. Sehingga hasil penelitian tersebut menunjukkan bahwa akibat terjadinya kasus Enron dan ImClone orang-orang menunjukkan penolakan yang lebih besar terhadap "accounting tricks" dan "insider trading". Kemudian mereka mencoba untuk menjelaskan hal tersebut dengan menggunakan Elaboration Likelihood Model, mereka mengemukakan bahwa perubahan sikap dapat terjadi melalui pengaruh media yang menurut Petty dan Cacioppo adalah "central route", dengan cara pengungkapan mendalam, terus-menerus, dan berulang ulang. Atau perubahan tersebut melalui "peripheral route", yaitu dengan dari informasi yang diperoleh, penerima informasi berpikir bahwa kasus Enron dan ImClone merupakan pelanggaran etika.

Menurut hasil penelitian yang dilakukan oleh Suharyat (2009) sikap dapat mempengaruhi perilaku melalui suatu proses pengambilan keputusan yang dilakukan dengan sangat teliti dan memiliki alasan, serta dapat berdampak, sebagai berikut: 1) Perilaku tidak banyak ditentukan oleh sikap umum tapi oleh sikap yang spesifik terhadap sesuatu. Sikap spesifik yang dapat mempengaruhi perilaku yaitu sikap sosial yang dilakukan secara berulang-ulang pada kegiatan yang sama atau yang biasa disebut kebiasaan, dorongan, keinginan dari dalam diri, serta norma-norma yang subjektif. 2) Perilaku dipengaruhi tidak hanya oleh sikap tetapi juga oleh norma-norma subjektif pada seseorang yaitu keyakinan kita mengenai apa yang orang lain inginkan untuk dilakukan. 3) Sikap terhadap suatu perilaku bersama norma-norma subjektif membentuk suatu intensi atau niat untuk berperilaku tertentu.

Aspek yang esensial dalam sikap adalah adanya perasaan atau emosi, kecenderungan terhadap perbuatan yang berhubungan dengan pengetahuan. Dari pengertian yang dikemukakan oleh Ellis (1950), sikap melibatkan suatu pengetahuan mengenai suatu situasi. Situasi tersebut dapat digambarkan sebagai suatu objek yang akan mempengaruhi perasaan atau emosi tersebut, dan kemudian memungkinkan munculnya suatu reaksi atau respons, dan atau kecenderungan untuk berbuat. Sebagai reaksi, sikap selalu berhubungan dengan dua alternatif perasaan yaitu senang (like) dan tidak senang (dislike) untuk melaksanakan atau menjauhinya. Teori belajar dalam ilmu psikologi menjelaskan bahwa terdapat struktur yang berpengaruh pada diri seorang individu dalam perkembangannya yaitu, (1) kognitif yang merupakan bagian dari pengetahuan dan pemahaman; (2) afeksi yang merupakan bagian dari perasaan, emosi, dan kemauan; (3) psikomotor yang berhubungan dengan fungsi fisik, seperti bertindak dan lain sebagainya. Dari ketiga aspek yang telah dijelaskan tersebut menunjukkan bahwa ketiganya memiliki pengaruh satu sama lain dalam setiap keputusan-keputusan yang diambil oleh seorang individu tersebut (Feist \& Feist, 2014). Mahasiswa sebagai kaum yang berintelektual dan pembawa perubahan (agent of change) sesuai dengan poin ketiga dari Tridharma Perguruan Tinggi yaitu pengabdian kepada masyarakat, yang nantinya akan mengabdikan dirinya bagi masyarakat, bangsa dan negara. sudah seharusnya memiliki sikap yang baik dalam pemrosesan informasi yang ada untuk menghadapi tantangan perkembangan media massa sehingga dapat 
memberikan kontribusi yang baik bagi masyarakat luas. Sehingga untuk menjadi pengguna sosial media yang baik, diperlukan sikap dalam menyaring informasi pada setiap pesan atau informasi yang ada di media sosial agar tidak menimbulkan perilaku yang merugikan dirinya maupun pihak lain.

Berdasarkan dari penjelasan yang telah dipaparkan, peneliti merumuskan masalah yang akan diteliti mengenai bagaimana sikap mahasiswa dalam memproses suatu informasi yang ia dapat di media sosial, dengan berfokus pada strategi dalam memproses informasi pada mahasiwa di media sosial. Serta bertujuan untuk mengetahui intensitas perilaku hate speech pengguna sosial media terhadap pemilihan strategi pemrosesan informasi atau pesan yang ada di media sosial. Penelitian ini dirasa penting dilakukan oleh peneliti karena melihat banyaknya kasus-kasus seperti ujaran kebencian (hate speech), bullying, sara, dan lain sebagainya di dalam media sosial. Penelitian ini diharapkan mampu memberikan informasi terkait dengan sikap dalam pemilihan strategi pemrosesan informasi para pengguna media sosial terkait dalam perspektif psikologi sosial, khususnya pada sikap seseorang dalam pemrosesan informasi yang didapat.

\section{METODE}

Penelitian ini menggunakan metode kuantitatif deskriptif. Sugiyono (2015), metode penelitian yang digunakan untuk meneliti populasi maupun sampel tertentu pada suatu penelitian, serta pada teknik pengambilan sempel umumnya dilakukan secara random sehingga kesimpulan dari hasil penelitian yang dilakukan dapat digeneralisasikan pada populasi maupun sampel diambil. Sedang penelitian deskriptif menurut Sugiyono (2015) adalah penelitian yang dilakukan untuk mengetahui nilai variabel mandiri, baik satu variabel maupun lebih (independen) tanpa membuat perbandingan atau menghubungkan variabel satu dengan variabel yang lainya. Dapat disimpulkan bahwa penelitian kuantitatif deskriptif merupakan penelitian yang dilakukan tanpa membandingkan atau menghubungkan antar variabel satu dengan lainnya, yang mana data yang diperoleh dari sampel populasi penelitian kemudian dianalisis sesuai dengan metode statistik deskriptif untuk dijelaskan.

Populasi penelitian adalah wilayah generalisasi yang terdiri atas objek atau subjek yang mempunyai kualitas dan karakteristik tertentu yang telah ditetapkan oleh peneliti untuk dipelajari, dianalisis, dan kemudian ditarik kesimpulan (Sugiyono, 2010). Populasi pada penelitian ini adalah mahasiswa atau yang berusia 18-25 tahun yang menggunakan media sosial.

Teknik pengambilan data yang digunakan oleh peneliti adalah teknik aksidental. Teknik aksidental merupakan penentuan sampel berdasarkan dari faktor spontanitas, sehingga siapa saja berhak menjadi subjek penelitian namun harus sesuai dengan karakteristik yang telah ditentukan oleh peneliti (Sugiono, 2001).

Variabel pada penelitian ini yaitu model pemrosesan informasi. Model pemrosesan informasi pada individu terdapat 2 strategi yaitu pemrosesan sistematis dan pemrosesan heuristik. Pemrosesan sistematis merupakan pemrosesan informasi terhadap pesan yang membutuhkan analisa yang mendalam dan berhati-hati. Sedangkan pemrosesan heuristik merupakan pemrosesan informasi terhadap pesan yang hanya menggunakan pemikiran sederhana sebagai pegangan atau jalan pintas. 
Adapun instrumen penelitian ini menggunkan kuisioner yang dibuat oleh peneliti berdasarkan identifikasi dan penjabaran karakteristik dari kedua strategi pemrosesan informasi yang kemudian oleh peneliti dirumuskan menjadi item-item berupa pernyataan maupun pertanyaan yang berjumlah 30 item. Terdiri dari 15 item favourable atau sistematik dan 15 item unfavourable atau heuristik. Kemudian, dari hasil uji validitas dan reliabilitas diperoleh hasil sejumlah 19 item valid dan 11 item yang gugur pada uji validitas dengan rentangan 0,228 dan angka reliabilitas bernilai 0,854. Sebanyak 12 item pertanyaan maupun pernyataan sistematik dan 7 pertanyaan maupun pernyataan heuristik. Skala yang digunakan merupakan skala likert. Pada skala pemrosesan informasi menggunakan klasifikasi pilihan jawaban, yaitu sangat setuju (SS), setuju (S), tidak setuju (TS) dan sangat tidak setuju (STS). Dalam mengukur intensitas perilaku hate speech penelitian ini menggunkan skala yang dibuat oleh peneliti sebanyak 10 item dan hasil uji validitas dan reliabilitas diperoleh hasil sejumlah 6 item yang valid, serta hasil validitas dengan rentangan 0,228 dan angka reliabilitas bernilai 0,854. Skala intensitas perilaku hate speech menggunakan 5 (lima) pilihan jawaban dengan skor 1,2,3,4,5 dan menggunakan klasifikasi pilihan jawaban, yaitu sering, hampir sering, selalu, kadang-kadang, tidak pernah.

Sebelum melakukan pengambilan data untuk penelitian ini, peneliti melakukan try out pada skala penelitian. Pengambilan subjek atau responden untuk melakukan try out didasari oleh karakteristik yang tidak jauh beda dengan subjek penelitian. Subjek penelitian dalam try out yang telah dilakukan ialah mahasiswa maupun remaja dengan rentangusia 18-25 tahun sebanyak 52 responden dan taraf kesalahan 5\%. Try out dilakukan mengunakan google form yang dilaksanakan pada tanggal 11 juni 2019 - 13 juni 2019.

Tahap kedua adalah tahap pelaksanaan penelitian. Pada tahap ini, peneliti melakukan peneitian pada tanggal 19 juni 2019 - 27 juni 2019. Sama halnya dengan dilakukannya try out, penelitian juga dilakukan dengan menggunakan subjek penelitian mahasiswa maupun remaja dengan rentan usia 19-25 tahun. Sebanyak 158 responden dan taraf kesalahan 5\%. Penelitian juga dilakukan mengunakan google form dengan pertanyaan maupun pernyataan pada item yang valid.

Selanjutnya, pada tahap terakhir adalah tahap analisa data penelitian. Setelah data diperoleh dari penyebaran skala, peneliti kemudian melakukan skoring terhadap skala-skala yang telah disebar. Setelah itu, peneliti memasukkan skor dari setiap item ke dalam Microsoft Excel 2013. Kemudian, data yang diperoleh dari Excel diproses menggunakan program SPSS (Statistical Program for Social Science) 21 for Windows untuk dianalisa dengan menggunakan uji deskriptif.

\section{HASIL}

Subjek dari penelitian ini terdiri dari pengguna aktif media sosial yang berjumlah sebanyak 158 orang, Mahasiswa atau yang berusia 19-25 tahun:

Tabel 1 Deskripsi subjek penelitian

\begin{tabular}{lcc}
\hline & Kategori & Jumlah \\
\hline Jenis Kelamin & & \\
& Laki-laki & 57
\end{tabular}




\begin{tabular}{llc} 
& Perempuan & 101 \\
& 19 tahun & 11 \\
20 tahun & 16 \\
21 tahun & 37 \\
22 tahun & 66 \\
23 tahun & 20 \\
24 tahun & 5 \\
25 tahun & 3 \\
\hline
\end{tabular}

Berdasarkan gambaran hasil Tabel 1. dapat dilihat bahwa 158 subjek penelitian ini didominasi perempuan sejumlah 101 orang serta didominasi oleh usia 22 tahun sebesar 66 orang.

Tabel 2. Penggunaan jenis pemrosesan informasi

\begin{tabular}{lll}
\hline Jenis pemrosesan informasi remaja & Jumlah & Persentase \\
\hline Sistematik & 56 & $35 \%$ \\
Heuristik & 97 & $61 \%$ \\
Sistematis/Heuristik & 5 & $3 \%$ \\
Total subjek & 158 & $100 \%$ \\
\hline
\end{tabular}

Berdasarkan pada Tabel 2. diketahui bahwa gambaran jenis pemrosesan informasi yang digunakan subjek menggunakan jenis pemrosesan informasi heuristik sebanyak 97 orang atau sebesar $61 \%$.

Kemudian, peneliti mengukur jenis pemrosesan informasi subjek berdasarkan jenis kelamin untuk melihat jumlah persentase jenis informasi yang digunakan dari masing-masing jenis kelamin pada subjek penelitian

Tabel 3. Penggunaan jenis pemrosesan informasi berdasarkan jenis kelamin

\begin{tabular}{llll}
\hline Jenis kelamin & \multicolumn{1}{c}{$\begin{array}{c}\text { Jenis Pemrosesan } \\
\text { Informasi }\end{array}$} & \multicolumn{1}{c}{ Jumlah } & \multicolumn{1}{c}{ Persentase } \\
\hline Laki-laki & Sistematik & 19 & $33 \%$ \\
& Heuristik & 38 & $67 \%$ \\
& Sistematis-Heuristik & - & - \\
\multirow{2}{*}{ Perempuan } & & $\mathbf{5 7}$ & $\mathbf{1 0 0} \%$ \\
& Sistematik & 37 & $37 \%$ \\
& Heuristik & 59 & $58 \%$ \\
Total & Sistematis-Heuristik & 5 & $5 \%$ \\
& & $\mathbf{1 0 1}$ & $\mathbf{1 0 0} \%$ \\
& & 158 & $100 \%$ \\
\hline
\end{tabular}

Berdasarkan hasil pada Tabel 3. dari hasil uji yang telah dilakukan, didapatkan hasil bahwa antara subjek dengan jenis kelamin laki-laki maupun perempuan keduanya cenderung menggunakan jenis pemrosesan heuristik dengan jumlah 38 subjek (67\%) dari total 57 subjek laki-laki dan 59 subjek (58\%) dari 101 subjek 
perempuan. Namun dapat dilihat pula bahwa subjek dengan jenis kelamin perempuan sebanyak 5 subjek (5\%) dari 101 subjek menggunakan jenis pemrosesan sistematisheuristik.

Selanjutnya peneliti menentukan jenis pemrosesan informasi berdasarkan rentang usia dari masing-masing subjek.

Tabel 4. Penggunaan jenis pemrosesan informasi berdasarkan usia

\begin{tabular}{cccc}
\hline Usia & Sistematis & Heuristik & Sistematis-Heuristik \\
\hline $19-20$ & $13(23 \%)$ & $13(13 \%)$ & $1(20 \%)$ \\
$21-22$ & $38(68 \%)$ & $64(66 \%)$ & $1(20 \%)$ \\
$23-25$ & $5(9 \%)$ & $20(21 \%)$ & $3(60 \%)$ \\
Total & $\mathbf{5 6 ( 1 0 0 \% )}$ & $\mathbf{9 7 ( 1 0 0 \% )}$ & $\mathbf{5 ( 1 0 0 \% )}$ \\
\hline
\end{tabular}

Berdasarkan hasil pada Tabel 4. dapat diketahui bahwa rata-rata jenis model pemrosesan informasi pada subjek penelitian cenderung menggunakan jenis pemrosesan informasi secara heuristik. Jika dilihat berdasarkan rentang usia, maka pada rentang usia 21-22 tahun lebih besar menggunakan jenis model pemrosesan heuristik dibandingkan dengan rentang usia lainnya. Selanjutnya peneliti melihat intensitas perilaku hate speech pengguna media sosial berdasarkan dari rentang usia masing-masing subjek.

Tabel 5. Intensitas perilaku hate speech pengguna media sosial berdasarkan rentang usia

\begin{tabular}{cccc}
\hline Usia & Rendah & Sedang & Tinggi \\
\hline $19-20$ & $10(20 \%)$ & $10(12,5 \%)$ & $7(25 \%)$ \\
$21-22$ & $31(62 \%)$ & $54(67,5 \%)$ & $18(64 \%)$ \\
$23-25$ & $9(18 \%)$ & $16(20 \%)$ & $3(11 \%)$ \\
Total & $\mathbf{5 0 ( 1 0 0 \% )}$ & $\mathbf{8 0 ( 1 0 0 \% )}$ & $\mathbf{2 8 ( 1 0 0 \% )}$ \\
\hline
\end{tabular}

Berdasarkan hasil pada Tabel 5. diketahui bahwa intensitas perilaku hate speech pada subjek secara keseluruhan dalam kategori sedang yaitu sebanyak 80 orang. Yang mana pada rentang usia 21-22 tahun memiliki skor tertinggi sebanyak 54 orang dibandingkan dari rentang usia lainnya. Selanjutnya, dilihat dari intensitas hate speech pada pemrosesan informasi.

Tabel 6. Intensitas perilaku hate speech dan pemrosesan informasi

\begin{tabular}{ccccccc}
\hline Item & $\begin{array}{c}\text { Jenis } \\
\text { Pemrosesan } \\
\text { Informasi }\end{array}$ & $\begin{array}{c}\text { Selalu- } \\
\text { Hampir } \\
\text { Selalu }\end{array}$ & Sering & $\begin{array}{c}\text { Kadang- } \\
\text { kadang }\end{array}$ & $\begin{array}{c}\text { Tidak } \\
\text { Pernah }\end{array}$ & Total \\
\hline \multirow{2}{*}{ Durasi } & Sistematik & $23(40 \%)$ & $16(25 \%)$ & $15(23 \%)$ & $7(12 \%)$ & $56(100 \%)$ \\
& Heuristik & $26(27 \%)$ & $24(25 \%)$ & $41(42 \%)$ & $5(5 \%)$ & $97(100 \%)$
\end{tabular}




\begin{tabular}{|c|c|c|c|c|c|c|}
\hline & $\begin{array}{l}\text { Sistematis- } \\
\text { Heuristik }\end{array}$ & $1(20 \%)$ & $2(40 \%)$ & $2(40 \%)$ & - & $5(100 \%)$ \\
\hline & & & & & Total & 158 \\
\hline \multirow[t]{4}{*}{ Durasi } & Sistematik & $16(28 \%)$ & $10(18 \%)$ & $19(34 \%)$ & $11(20 \%)$ & $56(100 \%)$ \\
\hline & Heuristik & $23(24 \%)$ & $17(17 \%)$ & $34(35 \%)$ & $23(24 \%)$ & $79(100 \%)$ \\
\hline & $\begin{array}{l}\text { Sistematis- } \\
\text { Heuristik }\end{array}$ & $4(80 \%)$ & - & - & $1(20 \%)$ & $5(100 \%)$ \\
\hline & & & & & Total & 158 \\
\hline \multirow[t]{4}{*}{ Frekuensi } & Sistematik & $16(28 \%)$ & $14(25 \%)$ & $10(18 \%)$ & $16(28 \%)$ & $56(100 \%)$ \\
\hline & Heuristik & $30(31 \%)$ & $16(16 \%)$ & $21(22 \%)$ & $30(31 \%)$ & $97(100 \%)$ \\
\hline & $\begin{array}{l}\text { Sistematik- } \\
\text { heuristik }\end{array}$ & $1(20 \%)$ & $1(20 \%)$ & $2(40 \%)$ & $1(20 \%)$ & $5(100 \%)$ \\
\hline & & & & & Total & 158 \\
\hline \multirow[t]{4}{*}{ Motivasi } & Sistematik & $2(4 \%)$ & $10(18 \%)$ & $10(18 \%)$ & $34(60 \%)$ & $56(100 \%)$ \\
\hline & Heuristik & $2(2 \%)$ & $5(5 \%)$ & $23(24 \%)$ & $67(69 \%)$ & $97(100 \%)$ \\
\hline & $\begin{array}{l}\text { Sistematik- } \\
\text { heuristik }\end{array}$ & - & - & $3(60 \%)$ & $2(40 \%)$ & $5(100 \%)$ \\
\hline & & & & & Total & 158 \\
\hline \multirow[t]{4}{*}{ Motivasi } & Sitematik & $1(2 \%)$ & $3(5 \%)$ & $8(14 \%)$ & 44 (79\%) & $56(100 \%)$ \\
\hline & Heuristik & $2(2 \%)$ & $1(1 \%)$ & $12(12 \%)$ & $82(85 \%)$ & $97(100 \%)$ \\
\hline & $\begin{array}{l}\text { Sistematik- } \\
\text { heuristik }\end{array}$ & - & - & - & $5(100 \%)$ & $5(100 \%)$ \\
\hline & & & & & Total & 158 \\
\hline \multirow[t]{4}{*}{ Frekuensi } & Sistematik & $6(11 \%)$ & $4(7 \%)$ & $14(25 \%)$ & 32 (57\%) & $56(100 \%)$ \\
\hline & Heuristik & $5(5 \%)$ & - & $15(15 \%)$ & $77(80 \%)$ & $97(100 \%)$ \\
\hline & $\begin{array}{l}\text { Sistematik- } \\
\text { heuristik }\end{array}$ & - & $2(40 \%)$ & $2(40 \%)$ & $1(20 \%)$ & $5(100 \%)$ \\
\hline & & & & & Total & 158 \\
\hline
\end{tabular}

Hasil yang didapat pada Tabel 6, menunjukkan bahwa durasi perilaku hate speech "Membuka akun media sosial" pada jenis pemrosesan informasi sistematik pilihan jawaban selalu-hampir selalu sebanyak 23 orang, sering 16 orang, kadang-kadang 15 orang dan tidak pernah 7 orang. Heuristik pilihan jawaban selalu-hampir selalu sebanyak 26 orang, sering 24 orang, kadang-kadang 41 orang dan tidak pernah 5 orang. Untuk pemrosesan sistematik-heuristik selalu-hampir selalu sebanyak 1 orang, sering 2 orang, dan kadang-kadang 2 orang. "Menggunakan akun untuk memantau berita selama 7 jam perhari" sistematik pilihan jawaban selalu-hampir selalu sebanyak 16 orang, sering 10 orang, kadang-kadang 19 orang dan tidak pernah 11 orang. Heuristik pilihan jawaban selalu-hampir selalu sebanyak 23 orang, sering 17 orang, kadangkadang 34 orang dan tidak pernah 23 orang. Untuk pemrosesan sistematik-heuristik selalu-hampir selalu sebanyak 4 orang dan tidak pernah 1 orang.

Frekunsi perilaku hate speech "Memiliki 3 akun medsos" sistematik pada pilihan jawaban selalu-hampir selalu sebanyak 16 orang, sering 14 orang, kadang-kadang 10 orang, dan tidak pernah 16 orang. Heuristik pada pilihan jawaban selalu-hampir selalu sebanyak 30 orang, sering 16 orang, kadang-kadang 21 orang dan tidak pernah 30 
orang. Pemrosesan sistematik-heuristik sebanyak 1 orang pada setiap pilihan jawaban selalu-hampir selalu, sering, dan tidak pernah, dan sebanyak 2 orang pada pilihan jawaban kadang-kadang. "Memiliki fake akun" dari jenis pemrosesan informasi sistematis pilihan jawaban selalu-hampir selalu 6 orang, sering 4 orang, kadangkadang 14 orang dan tidak pernah 32 orang. Pada heuristik pada pilihan jawaban selalu-hampir selalu sebesar 5 orang, kadang-kadang 15 orang, dan tidak pernah 77 orang. Untuk pemrosesan sistematik-heuristik pada pilihan jawaban sering sebanyak 2 orang, kadang-kadang sebanyak 2 orang, dan tidak pernah 1 orang.

Motivasi-tindakan perilaku hate speech "Mengikuti perkembangan berita di akun haters" pada pilihan jawaban selalu-hampir selalu sebanyak 2 orang, sering 10 orang, kadang-kadang 10 orang, dan tidak pernah 34 orang. Pada heuristik pada pilihan jawaban selalu-hampir selalu sebanyak 2 orang, sering 5 orang, kadang-kadang 23 orang, dan tidak pernah 67 orang. Untuk pemrosesan sistematik-heuristik pada pilihan jawaban kadang-kadang sebanyak 3 dan tidak pernah 2 orang. "Merepost postingan haters" sistematik pilihan jawaban selalu-hampir selalu sebanyak 1 orang, sering sebanyak orang, kadang-kadang 8 orang, dan tidak pernah 44 orang. Pada heuristik pada pilihan jawaban selalu-hampir selalu sebanyak 2 orang, sering 1 orang, kadangkadang 12 orang, dan tidak pernah 82 orang. Untuk pemrosesan sistematik-heuristik pada pilihan jawaban tidak pernah 5 orang.

\section{DISKUSI}

Penelitian yang telah dilakukan menunjukkan bahwa adanya kecenderungan pada mahasiswa dalam memproses sebuah informasi yang didapatkan di media sosial dengan menggunakan jenis pemrosesan secara heuristik yang artinya mahasiswa cenderung memiliki cara berfikir secara sederhana pada isi informasi yang diperoleh dari media sosial. Hal ini, dapat dibuktikan dengan hasil penelitian yang telah dilakukan menunjukkan bahwa sebanyak 97 responden (61\%) memilih untuk menggunakan jenis model pemrosesan secara heuristik dibandingkan dengan jenis model pemrosesan secara sistematis.

Berdasarkan hasil dari penelitian ini juga dapat diketahui bahwa kecenderungan jenis pemrosesan yang digunakan oleh mahasiswa laki-laki maupun perempuan, yaitu heuristik. Sebanyak 38 orang atau $67 \%$ mahasiswa laki-laki cenderung menggunakan jenis pemrosesan heuristik dari 57 orang, sedangkan mahasiswa perempuan sebanyak 59 orang atau 58\% dari 101 orang. Penelitian (Sina, 2014) menunjukkan hasil yakni subjek laki-laki memiliki kemampuan bernalar yang lebih tinggi, yang artinya bahwa seorang laki-laki akan lebih mampu dalam mengelola informasi secara terstruktur. sehingga seorang laki-laki akan cenderung memilih menggunakan jenis pemrosesan sistematis daripada seorang perempuan. Hal ini sesuai dengan hasil penelitian yang dilakukan oleh (Aini, 2017) bahwa pada pola pikir mahasiswa laki-laki maupun perempuan dalam langkah memahami suatu masalah tidak berbeda, namun ada perbedaan dalam menyikapi suatu permasalahan. Hal ini pula tidak sejalan dengan penelitian yang dilakukan oleh Indarto (2018) yang mana menunjukkan bahwa pengguna media sosial cenderung menggunakan model pemrosesan secara sistematis yang artinya sebagian besar pengguna media sosial berhati-hati dalam menerima informasi sebelum menerapkan atau membagikanya ke masyarakat sekitar. Selain itu 
menurut Nida (2014) besarnya pengaruh persuasi juga dapat dilihat dalam setiap pesan yang terdapat dalam media komunikasi massa atau media sosial, yang semuanya disajikan dalam tayangan visual maupun non visual seperti halnya pada sinetron, iklan, musik, film, humor maupun fashion.Yang mana mengartikan bahwa hasil penelitian pada penelitian ini berkemungkinan memiliki besar pengaruh persuasi pada setiap informasi yang ada di media sosial, sehingga rata-rata subjek menggunakan model pemrosesan secara heuristik.

Penelitian ini menggunakan subjek penelitian mahasiswa yang berusia 19-25 tahun. Berdasarkan hasil dari penelitian jika dilihat dari rentangan usia tersebut dapat diketahui bahwa mahasiswa pada rentang usia 21-22 tahun memiliki skor tertinggi daripada rentang usia lainnya, yang dapat diartikan bahwa mahasiswa dalam penelitian ini cenderung menggunakan jenis pemrosesan informasi secara heuristik, Hal ini sedikit bertentangan dengan teori perkembangan kognitif dari Piaget (dalam Santrock, 2007) yang menyatakan bahwa pada saat dewasa awal individu memasuki tahap pemikiran formal operasional, yang mana pada tahap dewasa awal individu memiliki pemikiran secara logis dan idealistik. Serta menurut beberapa ahli perkembangan mengemukakan bahwa di masa dewasa awal individu akan lebih berpikir secara sistematis dan terampil. Selain itu, menurut pemikiran post-formal (Santrock, 2007) pemikiran ini melibatkan pemahaman yang mendalam atas kebenaran secara terus-menerus dari suatu persoalan yang menuntut pemikiran reflektif dan keyakinan pada solusi secara realistis.

Hasil riset yang telah dilakukan oleh Yohan (2016) bahwa hate speech ialah bermasalahnya komunikasi verbal yang terjadi pada sejumlah mahasiswa yaitu seperti berkurangnya daya konsentrasi, frekuensi dan kesantunan dalam berkomunikasi sesuai akademik karena adanya keterikatan dengan komunikasi pada dunia maya, berkurangnya rasa percaya diri untuk berkomunikasi di kampus, khususnya dengan para dosen, karena adanya sebuah pelarian berupa "curhat" di media sosial (dalam Mawarti, 2018). Dilihat dari durasi perilaku hate speech "Membuka akun media sosial" pilihan jawaban selalu-hampir selalu pada jenis pemrosesan informasi sistematis dan heuristik mendapat nilai tertinggi. yaitu sebesar $40 \%$ dan $42 \%$, serta pada jenis pemrosesan informasi sistematis-heuristik sebanyak $40 \%$ pada pilihan jawaban sering dan kadang-kadang. Pada durasi "Menggunakan akun untuk memantau berita selama 7 jam perhari" sistematis mendapat nilai tertinggi sebesar $34 \%$ pada pilihan jawaban kadang-kadang, heuristik nilai tertinggi sebesar 35\% pada pilihan jawaban kadangkadang, serta pada jenis pemrosesan sistematik-heuristik nilai tertinggi sebesar $80 \%$ pada pilihan jawaban selalu-hampir selalu. Dilihat pada frekuensi "Memiliki 3 akun media sosial" sistematik mendapat nilai tertinggi pada pilihan jawaban selalu-hampir selalu dan tidak pernah sebesar $28 \%$, begitupun dengan heuristik mendapat hasil sebesar $31 \%$ pada pilihan jawaban selalu-hampir selalu dan tidak pernah, serta untuk sistematik-heuristik mendapat nilai yang sama sebesar $40 \%$ pada pilihan jawaban kadang-kadang. "Memiliki fake akun" pada pemrosesan sistematik sebesar 32\% pada pilihan jawaban tidak pernah, heuristik $80 \%$ pada pilihan jawaban tidak pernah dan pemrosesan sistematis-heuristik sebesar $40 \%$ pada pilihan jawaban sering dan kadangkadang. Motivasi dalam melakukan hate speech "Mengikuti perkembangan berita di akun haters" dan "Merepost postingan haters" cenderung mendapatkan nilai tertinggi 
pada pilihan jawaban tidak pernah baik pemrosesan informasi sistematis, heuristik dan sistematis-heuristik.

Menentukan jenis pemrosesan informasi memang sangat perlu untuk diperhatikan oleh setiap orang sebab banyaknya informasi yang ada di media sosial mampu memberikan dampak yang positif maupun negatif pada penggunanya. Penelitian yang dilakukan oleh Suharyat (2009) sikap dapat mempengaruhi perilaku melalui suatu proses pengambilan keputusan yang dilakukan dengan sangat teliti dan memiliki alasan, serta dapat berdampak untuk individu maupun orang lain, seperti kebiaasaan atau motivasi untuk berperilaku tertentu, keyakinan kita mengenai apa yang orang lain inginkan untuk dilakukan. Serta intensi atau niat untuk berperilaku tertentu. Hasil yang ditunjukkan dalam penelitian ini mimiliki nilai tinggi pada subjek yang menggunakan jenis model pemrosesan secara heuristik. Namun, di dalam penelitian ini pula menunjukkan hasil bahwa terdapat 5 subjek yang menggunakan jenis pemrosesan informasi sistematis-heuristik, yang artinya dari sekian banyak jumlah subjek sedikit orang yang menggunakan 2 jenis pemrosesan secara bersamaan. Penelitian yang dilakukan oleh Chaiken (1980) menemukan bahwa keterlibatan yang tinggi pada penerima informasi mengarahkan penerima pesan untuk menggunakan strategi pemrosesan informasi yang sistematis dimana kognisi berbasis pesan memediasi persuasi, sedangkan keterlibatan yang rendah menyebabkan penerima menggunakan strategi pemrosesan heuristik dimana aturan keputusan sederhana memediasi persuasi. Hal ini sejalan dengan konsep teori konsistensi (dalam, Hudaniah \& Dayakisni, 2012) manusia merupakan pelaku pemrosesan informasi yang aktif yang mencoba untuk memahami seluruhnya yang datang berdasarkan apa yang mereka rasakan, apa yang mereka pikirkan dan bersikap secara aktif untuk menyusun dan menafsirkan dunia tersebut untuk mencocokkan terhadap inkonsisten yang bisa terjadi antara sikap-sikap pada dirinya.

Meskipun dalam penelitian yang sudah didapatkan hasil bahwa sebanyak 97 orang menggunakan jenis model pemrosesan informasi secara heuristik pada intensitas perilaku hate speech pada pengguna media sosial. Namun, dalam penelitian ini masih belum mampu menunjukkan secara jelas dan rinci mengenai kemungkinan adanya faktor-faktor lain yang membuat pengguna media sosial melakukan perilaku hate speech di media sosial. Sehingga disini peneliti menyarankan kepada peneliti selanjutnya agar supaya dapat menjelaskan mengenai faktor-faktor yang dapat mempengaruhi perilaku hate speech di sosial media tersebut muncul. Selain itu informasi yang digunakan dalam penalitian ini tidak dijelaskan secara rinci bentuk informasi yang seperti apa dalam pengukurannya, sumber-sumber fenomena yang digunakan masih kurang valid hanya mengandalkan berita-berita yang ada di website saja. Hal tersebut menjadi kelemahan yang ada pada penelitian ini, sehingga membuat penelitian ini kurang bisa menggambarkan secara keseluruhan mengenai bagaimana faktor munculnya seseorang dapat melakukan perilaku hate speech di media sosial serta tidak mampu membuktikan kebenaran dari fenomena-fenomena yang dituliskan peneliti.

Penelitian dengan variabel ini masih jarang dilakukan di Indonesia dengan mengkaitkannya dalam bidang ilmu psikologi, sehingga hal tersebut menjadi salah satu keunikan dari penelitian ini. Pemilihan subjek juga menjadi keunikan tersendiri 
yang mana penelitian dengan subjek pelaku hate speech memang jarang ditemui walaupun kerap kali media sosial banyak diteliti. Hasil dari penelitian ini cukup jelas dan diharapkan bisa menjadi pengetahuan baru di dunia psikologi sosial khususnya dan bermanfaat bagi para pembaca. Namun, penelitian yang dilakukan oleh peneliti ini tak lepas dari kekurangan, dikarenakan dalam penelitian ini hanya berfokus untuk mengetahui jenis model pemrosesan informasi pada intensitas perilaku hate speech.

\section{SIMPULAN DAN IMPLIKASI}

Berdasarkan dari hasil penelitian yang telah dilakukan dapat disimpulkan bahwa mahasiwa pengguna media sosial cenderung menggunakan pemrosesan secara heuristik, yang mana sebagian besar pengguna media sosial cenderung berfikir secara sederhana terhadap isi informasi yang ada di media sosial. Hasil tersebut berlaku untuk jenis kelamin laki-laki maupun perempuan. Dalam penelitian ini juga menunjukkan bahwa intensitas perilaku hate speech dilihat dari pemrosesan informasinya memiliki nilai tertinggi pada pilihan jawaban tidak pernah.

Implikasi dari penelitian ini yaitu bagi pelaku media sosial agar mampu menggunakan kompetensi dalam menyaring informasi dan selalu berhati-hati, serta lebih selektif dalam menerima sebuah informasi yang ada di media sosial mengingat di era globalisasi atau media saturated era saat ini semua informasi dapat diakses dengan mudah hanya dengan melalui media sosial yang dimiliki oleh masyarakat.

Bagi peneliti selanjutnya, disarankan untuk dapat melakukan penelitian yang lebih mendalam mengenai faktor timbulnya perilaku hate speech pada pengguna media sosial serta pemrosesan informasi pada pengguna media, sehingga dapat diketahui lebih mendalam mengenai bagaimana perilaku itu dapat muncul, serta dapat pula memberikan gambaran yang sejelas-jelasnya mengenai kecenderungan sistem pemrosesan informasi yang digunakan pada setiap jenjangnya yang mengakibatkan munculnya perilaku-perilaku tertentu. Selain itu bagi peneliti selanjutnya agar lebih dapat menspesifikasikan objek dari hate yang dimaksudkan agar dapat lebih menjelaskan konteks dari perilaku yang disebut hate.

\section{REFERENSI}

Ahnaf, M.I., Suhadi. (2014). Isu-isu kunci ujaran kebencian (hate speech): implikasinya terhadap gerakan sosial membangun toleransi. Jurnal Multikultural dan Multireligius Vol. 13 No. 3 Desember 2014.

Aini, K., N. (2017). Proses berpikir mahasiswa laki-laki dan perempuan dengan gaya kognitif field independent dalam memecahkan masalah. Jurnal Inovasi Pendidikan dan Pembelajaran Matematika vol. 3 No. 1 Juni 2017.

Alloway. 2013. Social networking sites and cognitive abilities: do they make you smarter? Computer and Education, 63 : 10-16.

Anam, M. C., \& Hafiz, M. (2015). Surat edaran Kaporli tentang penanganan ujaran kebencian (hate speech) dalam kerangka hak asasi manusia. Jurnal keamanan Pusat Kajian Keamanan Nasional.

Arifin, J., Nursalam, N. (2016). Konstruksi sosial media komunikasi instagram terhadap pola pikir perilaku mahasiswa pendidikan sosiologi. Jurnal Equilibrium Pendidikan Sosiologi. Volume IV No. 2 November 2016 ISSN e-2477-0221 p-2339-2401. 
Asosiasi Penyelenggara Jasa Internet Indonesia, \& Polling Indonesia. (2016). Penetrasi dan perilaku internet indonesia 2016. Jakarta: Tim Polling Indonesia.

Asosiasi Penyelenggara Jasa Internet Indonesia, \& Teknopreneur. (2017). Penetrasi dan perilaku internet indonesia 2017. Jakarta: Teknopreneur.

Astarani, J. (2010). Penggunaan elaboration likelihood model dalam menganalisis penerimaan teknologi informasi. Jurnal Ekonomi, Bisnis dan Kewirausahaan. ISSN : 2087-9954. Volume 1, Nomor 2, Tahun 2010.

Azwar, Saifudin. (2002). Sikap Manusia: Teori dan Pengukurannya. Yogyakarta: Pustaka Pelajar.

Baron, R, A dan Byrne, D. 2004. Psikologi SosialEdisi 10. Jakarta : Erlangga.

Cahyono, A., S. (2016). Pengaruh media sosial terhadap perubahan sosial masyarakat di indonesia. Jurnal Publiciana 9(1), 140-157.

Chaiken, S. (1980). Heuristic versus systematic information processing and the use of source versus message cues in persuasion. Journal of Personality and Social Psychology 1980, Vol. 39, No. 5, 752-766.

Chaplin, J., P. (2006). Kamus lengkap psikologi. Jakarta: PT Raja Grafindo.

Choi, D., Yoo, W., Noh, G. \& Park, K. (2017). The impact of social media on risk perceptions during the mers outbreak in south korea. Computers In Human Behavior Vol 72 hal 422-431.

Ellis, R.S. (1950). Educational psychology: a problem approach. NewYork:d. Van Nostrard Co.

Feist, J., \& Feist, G. J. (2014). Teori kepribadian. Jld 2. Jakarta: Salemba Humaika.

Hidayat. (2016). 3 Media sosial favorit pengguna internet Indonesia. Diakses tanggal 28 Januari 2018 dari http://tekno.liputan6.com/read/2634027/3-media-sosial-favorit-pengguna-internetindonesia.

Hordecki, B. (2014). Contemporary research on hate speech in news websites' comments from the perspective of Jürgen Habermas's Theory of Knowledge. Research Report, Poland: The Adam Mickiewicz University, Faculty of Political Science and Journalism, St. Umultowska 89A, 61-614 Pozna ń, Poland.

Hudaniah., \& Dayakisni, T. (2012). Psikologi sosial. Malang:UMM Press.

Judhita, C. (2017). Hate speech di Media Online: Kasus Pilkada Dki Jakarta 2017. Artikel Ilmiah.

Kaplan, A. M \& Michael, H. (2010). Users of The World, Unite! The Challenges and Opportunities of Social Media. France: Business Horizons.

Kominfo. (2014). Riset kominfo dan UNICEF mengenai perilaku anak dan remaja dalam menggunakan internet. https://kominfo.go.id/index.php/content/detail/3834/siaran+pers+no.+17pikominfo22014+tentang+ riset+kominfo+dan+unicef+mengenai+perilaku+anak+dan+remaja+dalam+menggunakan +internet+/0/siaran pers. Diakses pada 18 februari 2014.

Krismanto, W., Yulia., Hasnah. (2017). Kemampuan menyusun skripsi ditinjau dari tingkat literasi media informasi. Jurnal Publikasi Pendidikan. Volume VII Nomor 1 Fabruari 2017 pISSN 2088-2092 e-ISSN 2548-6721.

Listiyani, D. (2017). Kenali sumber berita untuk melihat hoax. https://techno.okezone.com/read/2017/02/18/207/1621993/kenali-sumber berita-untuk-melihathoax. Diakses pada Sabtu 18 Februari 2017 16:19 WIB.

Lubis, E.E., Rumyeni. (2013). Analisis tingkat literasi media mahasiswa di jurusan ilmu komunikasi universitas riau. Artikel Ilmiah. Seminar Nasional, FISIP Univ. Riau "Politik, Birokrasi dan Perubahan Sosial dalam Upaya Membangun Karakter Bangsa".

Madinah. (2018). Anak dibully, ussy sulistiawaty perang dengan netizen. https://www.suara.com/entertainment/2018/12/02/183803/anak-dibully-ussy-sulistiawatyperang-dengan-netizen. Diakses pada Minggu, 02-12-2018 18:38 WIB. 
Mailanto, A. (2016). Pengguna instagram di Indonesia terbanyak, mencapai 89\%.https://techno.okezone.com/read/2016/01/14/207/1288332/pengguna-instagram-diindonesia-terbanyak-mencapai-89. Diakses pada Kamis 14 Januari 2016 18:50 WIB.

Mawarti, S. (2018). Fenomena hate speech dampak ujaran kebencian. Toleransi:Media Komunikasi umat Beragama Vol. 10, No. 1, Januari - Juni 2018

McQuail, D. (2003). Teori Komunikasi Massa. Jakarta: Erlangga.

Medistiara, Y. (2017). Selama 2017 porli tangani 3.325 kasus ujaran kebencian. https://news.detik.com/berita/d-3790973/selama-2017-polri-tangani-3325-kasus-ujarankebencian. Diakses pada Jumat 29 Desember 2017.

Minderop, A. (2016). Psikologi sastra: karya satra,metode, teori, dan contoh kasus edisi 2. Jakarta: Yayasan Pusat Obor.

Moriansyah, L., (2016). Motivasi, sikap, dan intensi pengguna media sosial pada kampanye stop illegal fishing.Jurnal Manajemen \& Agribisnis, Vol. 13 No. 3, November 2016.

Nathaniel, F. (2018). Ahmad dhani dan bahaya pasal karet uu ite yang tak kunjung dihapus. https://tirto.id/ahmad-dhani-dan-bahaya-pasal-karet-uu-ite-yang-tak-kunjung-dihapus-c77H. Diakses pada 20 Oktober 2018.

Nida, F. (2014). Persuasi dalam media komunikasi massa. Jurnal Komunikasi Penyiaran Islam, Volume 2, Nomor 2.

Nurhadiyanto, L. (2019) Strategi pencegahan kejahatan dengan kebencian (hate crime)melalui media mural di kelurahan kedoya utara, jakarta barat. IKRAITHABDIMAS Vol 2 No 1 Bulan Maret 2019.

Olisa, S. (2017). Indonesia negara terbesar ketiga pengguna sosmed Instagram. http://palembang.tribunnews.com/2017/04/02/indonesia-negara-terbesar-ketigapengguna-sosmedinstagram. Diakses pada Minggu, 2 April 2017.

Prawira, A. Y. (2016). Upaya kepolisian dalam menanggulangi kejahatan ujaran kebencian (Hate Speech. Bandar Lampung: Universitas Lampung.

Purnamasari, N. (2018). Wiranto: ada 53 kasus hoax dan 326 hate speech sepanjang 2018. https://news.detik.com/berita/d-4272642/wiranto-ada-53-kasus-hoax-dan-324hate-speech-sepanjang-2018. Diakses pada Kamis, 25 Oktober 2018, 14:00 WIB.

Rahman, Z. (2015). Surat edaran Kapolritentang ujaran kebencian (hate speech), akankah membelenggu kebebasan berpendapat ?. RechtsVinding Online jurnal Rechtsvinding media pembinaan hukum nasional ISSN 2089-9009.

Rakhmat, J. 2013. Psikologi komunikasi. Bandung : PT Remaja Rosdakarya.

Santrock, J. W. (2012). Life-Span development Jilid 2. Jakarta: Penerbit Erlangga.

Singh, M. (2016). Impact of students attitudes towards social media use ineducation on their academic performance. Journal of Management \& Research, Volume 10 Issue 2/4.

Sternberg, R. J. (2008). The nature of hate. Cambridge University Press.

Sternberg, R. J. (2005). Undestanding and combating hate. American Psychological Association.

Sugiyono. (2015). Metode penelitian kombinasi (mixed methods). Bandung: Alfabeta. P

Suharyat, Yayat. (2009). Hubungan antara sikap, minat, dan perilaku manusia. Jurnal REGION Volume I. No. 3. September 2009.

Supratman, L, P. (2018). Penggunaan media sosial oleh digital native. Jurnal Ilmu Komunikasi Volume 15, No 1, Juni 2018: 47-60.

Utami, E. (2014). 10 Hal yang paling diinginkan remaja. https://www.google.com. Diakses pada senin, 24 maret 2014.

Visanthi \& Padmapriya. (2016). Student's perception and attitude on social networking sites. Intercontinental Journal of Marketing Research Review,Vol 4 Issue 2.

Wicaksono, R, T. (2015). Jujur saja, topik-topik ini adalah topik yang sering dibaca anak muda. http://blog.penulis.id. Diakses pada 6 oktober 2015. 